\title{
Does Cultural Diversity of Board of Directors Affect Corporate Environmental Performance? Evidence From the Energy Sector
}

\author{
Nicola Varrone, PhD \\ Unversità della Campania-Luigi Vanvitelli, Italy \\ Eugenio D'Angelo, Associate Professor of Management \\ Pegaso Online University, Italy \\ Francesco Gangi, Full Professor of Management \\ Unversità della Campania-Luigi Vanvitelli, Italy \\ Lucia Michela Daniele, PhD \\ Unversità della Campania-Luigi Vanvitelli, Italy
}

Doi:10.19044/esj.2020.v16n28p287 URL:http://dx.doi.org/10.19044/esj.2020.v16n28p287

\begin{abstract}
This paper has a twofold objective. First, it intends to investigate if and how the cultural diversity of the board of directors affects the corporate environmental performance of energy firms. Second, it aims at verifying if the relationship between board cultural diversity and corporate environmental performance varies across different legal systems. To address this topic, panel data methodology was used on a sample of 153 firms operating in the energy sector, from 32 countries, over the period 2013-2018. The findings suggest that a higher board's cultural heterogeneity positively affects corporate environmental performance. Moreover, the study reveals that this link is stronger among energy firms from civil law countries compared to energy firms from common law countries.
\end{abstract}

Key Words: Board Cultural Diversity, Corporate Environmental

Performance, Energy firms, Institutional context 


\section{Introduction}

In recent years, civil society's concerns over climate change have grown considerably (Haque, 2017). Public attention has often involved large corporations, which are recognized among the major contributors to global warming (Downie and Stubbs, 2013). In 2017, the Carbon Disclosure Project has pointed out that 100 corporations have been responsible for $71 \%$ of the worldwide greenhouse gas emissions since 1998. The Kyoto protocol, entered in force in 2005, is considered the main driver of changes in corporate approaches to climate change (e.g. Lee et al., 2015). Indeed, relevant pressures for corporations to consider the climate consequences of their activities come also from consumers, governments, and policymakers (e.g. Haque, 2017). Among the various environmentally friendly activities, a growing number of firms has undertaken greenhouse gas emissions reduction initiatives to respond to the climate change challenges (Cadez and Czerny, 2016; Delmas and Toffel, 2008). This has led to an increasing number of studies investigating determinants and effects of corporate environmental performance (CEP) (e.g. Kim et al., 2015; Doda et al. 2016; Kleimeier and Viehs, 2018; Lemma et al., 2019).

This study intends to contribute to this stream of research analyzing the possible drivers of CEP in the energy sector. In particular, the purpose of the work is twofold: (i) to analyze the impact of board cultural diversity on CEP of energy firms; (ii) to verify if this relationship changes across different institutional contexts.

Some recent studies have analyzed how board characteristics affect corporate engagement in reducing carbon emissions. For example, Haque (2017) shows that board gender diversity and board independence favor the undertaking of carbon reduction initiatives. Haque and Ntim (2018), instead, suggest that firms with poor corporate governance mechanisms have worse CEP compared with their better-governed peers. Chams and Blandòn (2019) also report that the board's size and the average age of directors affect corporate sustainable performance.

However, nevertheless the growing number of empirical studies, recent literature recognizes the need for further investigations, analyzing the impact of board characteristics on firms' environmental performance (Haque and Ntim, 2018). In this regard, this study contributes to the existing literature in several ways.

First, the current research focuses on a less investigated board characteristic, such as the cultural diversity of board members. Consistent with prior investigations (e.g. Frijns et al., 2016), by cultural board diversity, this study means the portion of board members having a cultural background different from the location of corporate headquarter. To the best of our 
knowledge, this is the first study to analyze the impact of board cultural diversity on CEP in the energy sector.

Second, consistent with Busch and Lewandowski (2017), this study adopts the $\mathrm{CO} 2$ emissions normalized by firms' total assets to proxy CEP. This permits to focus on a specific dimension of corporate engagement in environmental issues. Indeed, while the main part of prior empirical investigations has adopted broader definitions of environmental performance (e.g. Garcia-Martin and Herrero, 2019), scant empirical evidence exists on the influence of board characteristics on $\mathrm{CO} 2$ emissions reduction initiatives.

Third, the research responds to the call by Gallego-Alvarez et al. (2015, p.8) for deeper investigations on how determinants of CEP vary across countries. Prior literature (e.g. Aguilera and Jackson 2010; Abdullah et al., 2016) suggests that the effectiveness of the decision of the board of directors may be shaped by the firm's institutional context. Thus, adopting the country classification proposed by La Porta (2008), the study verifies if the influence of board cultural diversity changes across different legal systems.

Finally, this research departs from the several multisector prior empirical studies (e.g. Jung et al., 2018). Authors recognize that the undertaking of environmentally responsible activities may vary significantly across industries (Dahlsrud, 2008), assuming peculiar traits in carbonintensive sectors (Loorbach et al., 2010; Cadez and Czerny, 2016). This is particularly true in the energy sector, where the challenges of the transition to low carbon economy appear even more urgent than other sectors (Cadez and Czerny, 2016; Kim et al., 2015). Energy firms are among the main greenhouse emitters, with more than 77\% of total EU emissions in 2017 (European Environment Agency, 2019). However, apart from a few exceptions (de Abreu et al., 2017), somewhat paradoxically empirical evidence regarding the CEP of energy firms is rare compared to the numerous studies adopting not sector-specific data (e.g. Landry et al., 2016).

Thus, drawing from several theoretical perspectives and adopting a sample of 153 energy firms from 32 countries, this research shows that the portion of board cultural diversity may affect CEP. The findings remain robust to the inclusion of several board and firm characteristics in our empirical models. Therefore, the remainder of this paper is organized as follows. First, the study discusses the theoretical background and formalizes the research hypotheses. Afterward, it describes the methodology and empirical strategy. Finally, the study presents results and conclusions. 


\section{Theoretical background and hypothesis development}

In this section, we discuss the theoretical foundations underlying the relationship between board cultural diversity and CEP. Moreover, we review the prior literature, which may help to explain if and how the effects of board cultural diversity on CEP vary across different institutional contexts.

According to Ferreira (2010), the board of directors represents the "most important decision-making body" in a firm. The characteristics of the board of directors such as the board size, independence, diversity, the directors' compensation policies are frequently considered as corporate governance mechanisms (e.g. Jain and Jamali, 2016).

From a theoretical point of view, the functioning of the board of directors has been the subject of significant evolution over the years. In particular, two main views have characterized the last decades. On one hand, drawing from the agency theory (Jensen and Meckling, 1976), authors have argued that the main function of the board of directors is to control that managers operate consistently with the interests of shareholders (Shleifer and Vishny, 1997). Thus, according to this perspective, the primary objective of the board of directors is to ensure shareholder wealth maximization (Gill, 2008). Following this reasoning line, managers are called to make as much money as possible in order to fulfill their fiduciary mandate towards the board's ownership (Friedman, 1970). From the perspective of the agency theory, corporate engagement in social and environmentally responsible initiatives is justified to the extent to which it is economically efficient (McWilliams and Siegel, 2001).

However, as recognized by prior literature (e.g. Berrone and GomezMejia, 2009), the engagement of socially and environmentally responsible may require substantial investments, which present only uncertain and longterm returns. In the perspective of agency theory (Jensen and Meckling, 1976), this may induce manager to avoid the undertaking of socially and environmentally responsible initiatives and to invest in activities which ensure short term profits, in order to fulfill their fiduciary mandate towards shareholders. On the other hand, a more recent view argues that the board of directors has a broader function, which encompasses responsibilities not only towards shareholders but also towards other stakeholders (MacMillan et al, 2004; Page, 2005). According to this perspective, a good board of directors should promote initiatives, such as the investment in socially and environmentally responsible activities, which improve the relationship with stakeholders (e.g. Jo and Harjoto, 2011). This view, also known as the "conflict resolution hypothesis" (e.g. Calton and Payne 2003), argues that effective corporate governance mechanisms permit to align the long-term goals of managers and stakeholders. In this regard, the real challenge for the 
board of directors is to solicit managers' decisions that are at the same time profitable and socially responsible (Carroll, 2000).

Drawing from these theoretical perspectives, several prior empirical studies have investigated how board's characteristics, such as board gender diversity (Garcia Martin and Herrero, 2019), board independence (Liao et al., 2015, Haque, 2017), board size (De Villiers et al., 2011), affect corporate environmental performance. However, despite the growing number of studies on board characteristics, scant attention has been paid to board cultural diversity (Frijns et al., 2016). To complement prior literature, the current research analyzes how the cultural diversity of the board of directors affect the CEP of energy firms.

\section{Board cultural diversity and corporate environmental performance}

Over the last decades, cultural diversity has become an increasingly relevant phenomenon that involves social and political implications (Lozano and Escrich, 2017). Indeed, the growing cultural diversity appears as a consequence of socio-economic phenomena, such as globalization or the increasing number of worldwide migrants (OECD, 2019). Das Neves and Mele (2013) define cultural diversity as "the quality of diverse or different cultures", which may be found in a certain context.

As a reflection of the widespread cultural diversity in civil society, over the last years, companies are gradually becoming more and more multicultural organizations (Dias et al., 2020). In a recent report, Deloitte (2018) indicates that two-thirds, of 10,000 corporate leaders interviewed, declared that diversity and inclusion are crucial topics for their businesses. This trend challenges business decisions and operations, to the extent to which cultural diversity, within an organization, requires the integration of different belief, customs, perceptions, educational backgrounds, religions, information-processing approaches, and decision-making styles (e.g. Maznevski 1994; Tsui and O’Reilly 1989). Moreover, Lozano and Escrich (2017) argue that the management of diversity within organizations involves not only business issues but also the attention to ethical and moral needs.

As suggested by prior literature, cultural diversity in workgroups may exert two kinds of opposing effects on corporate outcomes (Milliken and Martins, 1996). In particular, on one hand, prior studies have suggested that cultural diversity may create business frictions (Frijns et al., 2016), making it harder the coordination and communication among individuals (Anderson et al., 2011). On the other hand, the authors suggest that cultural diversity may be beneficial for team performance. For example, Nederveen Pieterse et al. (2013) indicate that cultural diversity may enrich the decision-making process, bringing heterogeneity in terms of views, ideas, opinions, information processing approaches. 
From the perspective of CEP, even though recent empirical studies have investigated how board characteristics influence corporate environmental performance (e.g. Haque 2017; Naciti, 2019), scant attention has been paid to the board's cultural diversity. To extend prior literature, grounding in the debate regarding the effects of workgroup cultural diversity (Milliken and Martins, 1996), the current research proposes that board cultural diversity influences the effectiveness of the board's decisions regarding environmental issues. In line with these arguments, the study hypothesizes the following:

H.1 Board cultural diversity affects corporate environmental performance in the energy sector

Board cultural diversity, corporate environmental performance and institutional context.

The effectiveness of the board of directors' decisions may be shaped by the firm's institutional context (e.g. Aguilera and Jackson 2010; Abdullah et al., 2016). From the sustainability perspective, prior literature recognizes that institutional contexts may influence the firm's engagement in social and environmental responsibility (Sharfman et al., 2004). Haque and Ntim, (2018) suggest that economic, political, or legislative pressures may lead firms to undertake socially and environmentally responsible initiatives.

In this regard, the current research intends to verify if the impact of board cultural diversity on CEP varies across different institutional contexts. Among the various institutional factors that may influence environmental performance (Gallego-Alvarez et al., 2015), the study focuses on the country's legislative origins. More specifically, drawing from La Porta et al. (2008), the research distinguishes between countries with "civil law" legal origins and "common law" legal origins. La Porta et al. (2008) suggest that countries' "legal origins have significant consequences for the legal and regulatory framework of the society, as well as for economic outcomes". Indeed, relevant differences exist between the two legislative origins. Common law systems have Anglo-Saxon origins and are characterized by a low degree of codification, fewer restrictions on directors' decisions, and higher protection towards shareholders. Civil law systems draw their origins from Roman, German, or Scandinavian law traditions and are characterized by higher government presence in corporate capital structure, stronger labor protection legislation (Liang and Renneboog, 2017). From a CEP perspective, drawing from La Porta et al. (2008) legal systems' classification, recent studies have demonstrated that corporate engagement in socially and environmentally activities may vary across legal systems. For example, Liang and Renneboog (2017) analyzing a sample of 23,000 companies from 114 countries find that companies from civil law countries 
have higher corporate social responsibility ratings than companies from civil law countries. The authors argue that some characteristics of civil law systems such as rule-based managerial constraints, lower shareholder litigation risk, stronger labor legislation, and high involvement of the state in businesses may lead firms to have better social and environmental performance than firms from common law countries.

Kock and Min (2015), instead, argue that common law systems, being characterized by corporate governance mechanisms that emphasize shareholder protection, tend to be associated with worse environmental performance than civil law systems.

Thus, motivated by the above studies, the current research assumes that the positive influence of board cultural diversity on corporate environmental performance varies across different countries' legal origins. In particular, we expect that a higher cultural heterogeneity on board of directors has a higher positive impact on corporate environmental performance for companies from civil law countries than for companies from common law countries. In line with these arguments, the study hypothesizes the following:

H.2 Board cultural diversity has a higher positive influence on corporate environmental performance for firms from civil law countries compared to firms from common law countries.

\section{Research design and methodology}

\section{Data collection and sampling procedure}

To test our research hypotheses, the study analyses an international sample of energy firms over the period 2013-2018. In particular, through the Thomson Reuters "Screener" tool, the study identifies an initial list of 1855 firms operating in the energy sector.

Regarding the data employed in the empirical analysis, we begin collecting the data on the firm's $\mathrm{CO} 2$ emissions from Asset4. This latter provides one of the most complete ESG databases, comprising more than 7,000 companies, with time series data going back to 2002 (Thomson Reuters ESG Scores, 2018). It is widely adopted by prior literature investigating corporate environmental performance (e.g. Graafland, 2019). Prior studies (e.g. Ortas et al., 2019) document that Asset4 offers objective, comparable and transparent evaluations regarding firms' engagement in environmental issues.

We match the initial list of energy firms, obtained by Thomson Reuters, with the data on $\mathrm{CO} 2$ emissions collected through Asset4. After the removal of companies for which Asset4 does not report data on $\mathrm{CO} 2$ emission, we obtain a list of 213 energy firms. The research relies on Asset 4 also to collect 
data on the board of directors' characteristics. Once again, we are forced to remove further 42 firms because of missing data on variables regarding the characteristics of the board of directors. Finally, the research refers to the Worldscope database to collect financial data. After the removal of companies for which Worldscope does not disclose financial data, we obtain a final sample of 153 energy firms, over the period 2013-2018. Table 1 reports the sample breakdown by companies' countries of headquarter.

Table 1. Sample breakdown by country.

\begin{tabular}{lcclcc}
\hline Country & Company & $\%$ & Country & Company & $\%$ \\
\hline Argentina & 1 & $1 \%$ & India & 6 & $4 \%$ \\
Austria & 2 & $1 \%$ & Italy & 4 & $3 \%$ \\
Australia & 8 & $5 \%$ & Japan & 6 & $4 \%$ \\
Belgium & 1 & $1 \%$ & Luxembourg & 1 & $1 \%$ \\
Brazil & 1 & $1 \%$ & Malaysia & 2 & $1 \%$ \\
Canada & 13 & $9 \%$ & Netherlands & 4 & $3 \%$ \\
China & 4 & $3 \%$ & Norway & 12 & $8 \%$ \\
Denmark & 1 & $1 \%$ & New Zealand & 2 & $1 \%$ \\
Spain & 2 & $1 \%$ & Poland & 2 & $1 \%$ \\
Finland & 1 & $1 \%$ & Portugal & 1 & $1 \%$ \\
France & 6 & $4 \%$ & Russian Federation & 5 & $3 \%$ \\
United Kingdom & 20 & $13 \%$ & Sweden & 1 & $1 \%$ \\
Greece & 1 & $1 \%$ & Thailand & 5 & $3 \%$ \\
Hong Kong & 5 & $3 \%$ & Turkey & 1 & $1 \%$ \\
Hungary & 1 & $1 \%$ & United States & 32 & $21 \%$ \\
Indonesia & 1 & $1 \%$ & South Africa & 1 & $1 \%$ \\
\hline & & & Tot. & 153 & $100 \%$ \\
\hline
\end{tabular}

\section{Variables}

This section describes the variables employed in the empirical analysis. In particular, the first subsection refers to the dependent variable (CEP), the second subsection describes the independent variable (Board cultural diversity), finally, the last subsection reports the description of the control variables.

\section{Corporate environmental performance measure}

Consistent with previous studies (e.g. Gallego Alvarez et al 2015), the current research refers to $\mathrm{CO} 2$ emissions to measure corporate environmental performance. In particular, in line with Busch and Lewandowski (2017), the indicator of CEP adopted in the empirical analysis is obtained by dividing the total $\mathrm{CO} 2$ equivalent emissions by the company's 
total assets. Accordingly, firms with a higher CEP indicator present a higher amount of $\mathrm{CO} 2$ emissions and thus a worse environmental performance.

\section{Board cultural diversity indicator}

Cultural diversity of the board of directors was used as an independent variable as the research objective is to test the relationship between board cultural heterogeneity and CEP of energy firms. The study collects the information on board cultural diversity from the Asset 4 database. Similar to prior literature (e.g. Frijns et al., 2016), the variable employed in the empirical analysis (Board Cultural diversity) expresses the percentage of board members having a cultural background different from the location of the corporate headquarters.

\section{Control variables and institutional context classification}

Corporate environmental performance may be influenced by several characteristics of the firm and its management. Therefore, the current study includes several control variables in the empirical analysis. First, consistent with prior literature investigating the influence of board characteristics on corporate environmental performance (e.g. Haque, 2017), we control for: board independence (percentage of independent directors); board gender diversity (percentage of female directors); CEO duality (CEO simultaneously chair the board); CEO compensation (CEO's compensation is linked to total shareholder return). In line with Garcia Martin and Herrero (2019), we control for firm profitability, including the Return on investments (Roi), firm leverage, including the Debt to total capital ratio and the Debt to equity ratio, and firm size, including the company's number of employees. Furthermore, we include a dummy variable regarding the presence of a Sustainability Committee, which assumes value 1 if the company has a corporate social responsibility committee, 0 otherwise. Finally, we refer to La Porta et al. (2008) to distinguish between firms having the headquarter in civil law countries and those having the headquarter in common law countries.

\section{Empirical strategy}

The study adopts the analysis of panel data to test the research hypotheses. In particular, the research employs a pooled cross-sectional ordinary least squares (OLS) regression with robust standard errors (Wooldridge, 2002) to determine the impact of board's cultural diversity on CEP. The quantitative analysis of panel data is considered the most appropriate empirical approach if data have both time-series and crosssectional dimensions (Gujarati, 2003). The regression equation is formalized as follows: 
CEP i,t $=\alpha+\beta$ Board C. Div. i,t $+\psi$ X i,t $+\varepsilon$ i,t,

where CEP $i, t$ denotes the corporate environmental performance of firm $i$ at time $t$; Board C. Div. is the cultural diversity on board of firm i at time t; X i, $\mathrm{t}$ is a vector of the control variables; and $\varepsilon \mathrm{i}, \mathrm{t}$ is the random error term. Note that the study estimates the equation (1) 8 times. In particular, the research applies 4 models on the full sample, 2 models considering the firms that have the headquarter in civil law countries, and 2 models including the firms that have the headquarter in common law countries.

\section{Results}

Descriptive analysis

Table 2 displays sample descriptive statistics. In particular, it compares the number of observations, the mean and the standard deviation between energy firms with low board cultural diversity (the Board cultural diversity variable is lower than the median value of the sample) and energy firms with high board cultural diversity (the Board cultural diversity variable is higher than the median value of the sample). In particular, the former present a higher amount of $\mathrm{CO} 2$ emissions (21.09), compared to the latter (17.30). Moreover, firms with low board cultural diversity have a higher portion of independent directors (Board independence), a higher representation of female directors (Board gender diversity) are larger (Size) and more indebted than firms with high board cultural diversity.

Table 2. Decriptive statistics.

\begin{tabular}{l|cccccc}
\hline \multirow{2}{*}{ Variable } & \multicolumn{3}{c}{ Low Board cultural diversity } & \multicolumn{3}{c}{ High Board cultural diversity } \\
\cline { 2 - 7 } & Obs & Mean & Std. Dev. & Obs & Mean & Std. Dev. \\
\hline CEP & 254 & 21.09 & 30.77 & 745 & 17.30 & 25.32 \\
Board independence & 290 & 54.48 & 28.81 & 892 & 53.23 & 30.15 \\
Board gender diversity & 290 & 15.91 & 10.86 & 892 & 14.30 & 13.05 \\
Sustainability committec & 290 & 0.77 & 0.41 & 894 & 0.71 & 0.45 \\
Size & 267 & 18497.24 & 36896.84 & 944 & 18076.74 & 46358.81 \\
Debt to total capital & 290 & 37.40 & 66.75 & 1045 & 37.13 & 25.81 \\
Debt to equity & 288 & 81.67 & 134.65 & 1045 & 142.94 & 2091.57 \\
Roi & 290 & 3.85 & 14.94 & 1032 & 5.41 & 16.63 \\
CEO Duality & 290 & 0.27 & 0.44 & 894 & 0.27 & 0.44 \\
CEO compensation & 290 & 0.58 & 0.49 & 894 & 0.50 & 0.50 \\
\hline
\end{tabular}

\section{Multivariate analysis}

Table 3 shows the results of the regression analysis regarding the impact of board cultural diversity on CEP. In addition to the independent variable (Board cultural diversity), the regression models include several 
control variables regarding the board characteristics (Board independence, Board gender diversity, CEO duality, CEO compensation) and firm characteristics (Size, Debt to total capital, Debt to equity, Sustainability committee, Roi). Models 1 and 2 highlight a negative and statistically significant coefficient (at the confidence level of $10 \%$ or less) on the variable Board cultural diversity, indicating that the higher is the board's cultural heterogeneity the lower is the amount of $\mathrm{CO} 2$ emission of energy firms. As a robustness check, models 3 and 4 use the Debt to equity ratio to proxy the firm leverage instead of the Debt to total capital ratio adopted in models 1 and 2. Once again, the results indicate that a higher board's cultural diversity is a driver of lower levels of $\mathrm{CO} 2$ emissions, confirming the research hypothesis H1. Our empirical evidence is aligned with prior investigations (e.g. Birindelli et al., 2019) which report a positive influence of board gender diversity on CEP. Our findings are, instead, not consistent with Frijns et al. (2016), that highlight a negative influence of board cultural diversity on firm financial performance.

Table 3. Multivariate analysis (full sample)

This table presents the results of the pooled OLS estimations including the Board cultural diversity as independent variable. The dependent is the corporate environmental performance (CEP). The t-statistics are adjusted for robust and clustered (by firm) standard errors and reported in round brackets. ${ }^{* * *}$ Statistically significant at $1 \%$ level. ${ }^{* *}$ Statistically significant at $5 \%$ level. *Statistically significant at $10 \%$ level.

\begin{tabular}{|c|c|c|c|c|}
\hline Variable & $\begin{array}{l}\text { CEP } \\
(1) \\
\end{array}$ & $\begin{array}{l}\text { CEP } \\
(2) \\
\end{array}$ & $\begin{array}{l}\text { CEP } \\
(3) \\
\end{array}$ & $\begin{array}{l}\text { CEP } \\
(4) \\
\end{array}$ \\
\hline Board cultural diversity & $\begin{array}{c}-0.087^{*} \\
(-1.94)\end{array}$ & $\begin{array}{c}-0.092^{* *} \\
(-2.00)\end{array}$ & $\begin{array}{l}-0.084^{*} \\
(-1.85)\end{array}$ & $\begin{array}{l}-0.090^{*} \\
(-1.90)\end{array}$ \\
\hline Size & $\begin{array}{l}-0.000 \\
(-0.87)\end{array}$ & $\begin{array}{l}-0.000 \\
(-0.84)\end{array}$ & $\begin{array}{l}-0.000 \\
(-0.80)\end{array}$ & $\begin{array}{l}-0.000 \\
(-0.77)\end{array}$ \\
\hline Debt to total capital & $\begin{array}{l}0.028 \\
(1.11)\end{array}$ & $\begin{array}{l}0.030 \\
(1.04)\end{array}$ & & \\
\hline Debt to equity & & & $\begin{array}{c}0.009 * * \\
(2.28)\end{array}$ & $\begin{array}{c}0.009 * * \\
(2.19)\end{array}$ \\
\hline Roi & $\begin{array}{l}0.226 \\
(1.44)\end{array}$ & $\begin{array}{l}0.256 \\
(1.41)\end{array}$ & $\begin{array}{l}0.157 \\
(1.36)\end{array}$ & $\begin{array}{l}0.177 \\
(1.36)\end{array}$ \\
\hline Board independence & $\begin{array}{l}0.147^{*} \\
(1.93)\end{array}$ & $\begin{array}{c}0.151^{* *} \\
(2.03)\end{array}$ & $\begin{array}{l}0.136^{*} \\
(1.80)\end{array}$ & $\begin{array}{l}0.141^{*} \\
(1.90)\end{array}$ \\
\hline Board gender diversity & $\begin{array}{l}0.085 \\
(0.79)\end{array}$ & $\begin{array}{l}0.073 \\
(0.68)\end{array}$ & $\begin{array}{l}0.103 \\
(0.94)\end{array}$ & $\begin{array}{l}0.092 \\
(0.84)\end{array}$ \\
\hline Sustainability committee & $\begin{array}{c}-17.514^{* * *} \\
(-2.64)\end{array}$ & $\begin{array}{c}-17.364^{* * *} \\
(-2.63)\end{array}$ & $\begin{array}{c}-17.068^{* *} \\
(-2.59)\end{array}$ & $\begin{array}{c}-16.966 * * \\
(-2.59)\end{array}$ \\
\hline CEO Duality & $\begin{array}{l}-1.892 \\
(-0.59)\end{array}$ & $\begin{array}{l}-1.987 \\
(-0.61)\end{array}$ & $\begin{array}{l}-1.496 \\
(-0.46)\end{array}$ & $\begin{array}{l}-1.591 \\
(-0.49)\end{array}$ \\
\hline CEO compensation & $\begin{array}{l}5.015 \\
(0.95)\end{array}$ & $\begin{array}{l}5.058 \\
(0.95)\end{array}$ & $\begin{array}{l}5.407 \\
(1.03)\end{array}$ & $\begin{array}{l}5.417 \\
(1.04)\end{array}$ \\
\hline Year & No & Yes & No & Yes \\
\hline _cons & $\begin{array}{c}23.758^{* * *} \\
(3.08)\end{array}$ & $\begin{array}{c}23.917^{* * *} \\
(3.07)\end{array}$ & $\begin{array}{c}23.637^{* * *} \\
(2.91)\end{array}$ & $\begin{array}{c}24.271^{* * *} \\
(2.94)\end{array}$ \\
\hline No. of Obs. & 352.00 & 352.00 & 352.00 & 352.00 \\
\hline R-Squared & 0.08 & 0.09 & 0.08 & 0.09 \\
\hline
\end{tabular}


Table 4, instead, reports the regression analysis regarding the energy firms from civil law countries (models 1 and 2) and the energy firms from common law countries (models 3 and 4). In models 1 and 2, the Board cultural diversity exhibits negative and strongly statistically significant coefficients $(t=-3.12)$, at a confidence level of $1 \%$. Regarding the energy firms from common law countries, the coefficient of Board cultural diversity is not statistically significant in model 3 and statistically significant, at a confidence level of $10 \%$, in model 4.

Table 4. Multivariate analysis (Civil and common law countries)

This table presents the results of the pooled OLS estimations including the Board cultural diversity as independent variable. The dependent is the corporate environmental performance (CEP). Models 1 and 2 refer to firms from civil law countries, while Models 3 and 4 refer to firms from common law countries The t-statistics are adjusted for robust and clustered (by firm) standard errors and reported in round brackets. ${ }^{* * *}$ Statistically significant at $1 \%$ level. ${ }^{* *}$ Statistically significant at $5 \%$ level. *Statistically significant at $10 \%$ level.

\begin{tabular}{|c|c|c|c|c|}
\hline Variable & $\begin{array}{c}\text { CEP } \\
(1) \\
\text { Civil law } \\
\end{array}$ & $\begin{array}{c}\text { CEP } \\
(2) \\
\text { Civil law }\end{array}$ & $\begin{array}{c}\text { CEP } \\
\text { (3) } \\
\text { Common law }\end{array}$ & $\begin{array}{c}\text { CEP } \\
(4) \\
\text { Common law }\end{array}$ \\
\hline Board cultural diversity & $\begin{array}{c}-0.327^{* * * *} \\
(-3.12)\end{array}$ & $\begin{array}{c}-0.346^{* * *} \\
(-3.12)\end{array}$ & $\begin{array}{l}-0.069 \\
(-1.63)\end{array}$ & $\begin{array}{c}-0.076^{*} \\
(-1.66)\end{array}$ \\
\hline Size & $\begin{array}{l}0.000^{*} \\
(1.77)\end{array}$ & $\begin{array}{c}0.000^{* *} \\
(2.02)\end{array}$ & $\begin{array}{c}0.000^{* *} \\
(2.32)\end{array}$ & $\begin{array}{c}0.000^{* *} \\
(2.29)\end{array}$ \\
\hline Debt to total capital & $\begin{array}{l}0.035 \\
(0.21)\end{array}$ & $\begin{array}{l}0.043 \\
(0.25)\end{array}$ & $\begin{array}{l}0.001 \\
(0.03)\end{array}$ & $\begin{array}{l}0.002 \\
(0.10)\end{array}$ \\
\hline Roi & $\begin{array}{l}0.515 \\
(1.43)\end{array}$ & $\begin{array}{l}0.565 \\
(1.42)\end{array}$ & $\begin{array}{l}0.026 \\
(0.23)\end{array}$ & $\begin{array}{l}0.047 \\
(0.39)\end{array}$ \\
\hline Board independence & $\begin{array}{l}0.008 \\
(0.04)\end{array}$ & $\begin{array}{l}0.022 \\
(0.13)\end{array}$ & $\begin{array}{c}0.195 * * * \\
(3.00)\end{array}$ & $\begin{array}{c}0.200^{* * *} \\
(3.09)\end{array}$ \\
\hline Board gender diversity & $\begin{array}{l}-0.266 \\
(-1.49)\end{array}$ & $\begin{array}{l}-0.341^{*} \\
(-1.76)\end{array}$ & $\begin{array}{l}-0.110 \\
(-0.66)\end{array}$ & $\begin{array}{l}-0.141 \\
(-0.79)\end{array}$ \\
\hline Sustainability committee & $\begin{array}{c}-41.559 * * * \\
(-2.70)\end{array}$ & $\begin{array}{c}-41.701^{* * *} \\
(-2.71)\end{array}$ & $\begin{array}{l}-6.386 \\
(-1.38)\end{array}$ & $\begin{array}{l}-6.102 \\
(-1.33)\end{array}$ \\
\hline CEO Duality & $\begin{array}{l}5.242 \\
(0.66)\end{array}$ & $\begin{array}{l}4.238 \\
(0.51)\end{array}$ & $\begin{array}{c}-8.938^{* * *} \\
(-4.00)\end{array}$ & $\begin{array}{c}-9.293 * * * \\
(-3.91)\end{array}$ \\
\hline CEO compensation & $\begin{array}{c}21.952^{*} \\
(1.96)\end{array}$ & $\begin{array}{c}21.696^{* *} \\
(1.99)\end{array}$ & $\begin{array}{l}2.310 \\
(0.54)\end{array}$ & $\begin{array}{l}2.850 \\
(0.63)\end{array}$ \\
\hline $\begin{array}{l}\text { Year } \\
\text { _cons }\end{array}$ & $\begin{array}{c}\text { No } \\
60.220^{* * *} \\
(3.27)\end{array}$ & $\begin{array}{c}\text { Yes } \\
57.862^{* * * *} \\
(3.20)\end{array}$ & $\begin{array}{c}\text { No } \\
15.452^{* * *} \\
(2.14)\end{array}$ & $\begin{array}{c}\text { Yes } \\
14.401^{* *} \\
(2.00)\end{array}$ \\
\hline $\begin{array}{l}\text { No. of Obs. } \\
\text { R-Squared }\end{array}$ & $\begin{array}{c}141.00 \\
0.23\end{array}$ & $\begin{array}{c}141.00 \\
0.25\end{array}$ & $\begin{array}{c}192.00 \\
0.15\end{array}$ & $\begin{array}{c}192.00 \\
0.15\end{array}$ \\
\hline
\end{tabular}

As a whole, the estimates reported in Table 4 suggest that board cultural diversity contributes to reduce $\mathrm{CO} 2$ emissions to a greater extent for energy firms from civil law countries, compared to energy firms from common law countries. These results permit to confirm the research hypothesis H2. Regarding the control variables, board independence presents positive and statistically significant coefficients, indicating that firms with a higher number of independent directors present a higher amount of $\mathrm{CO} 2$ emissions. The presence of a corporate social responsibility committee, instead, appears among the main driver of $\mathrm{CO} 2$ emission reduction. 


\section{Conclusion}

The current research has analyzed how the cultural diversity on the board of directors affects the energy firms' CEP, with specific reference to the amount of $\mathrm{CO} 2$ emissions. Moreover, the study has investigated if this link varies across different legal systems.

In the first step, the research reveals that the board's cultural heterogeneity favors the achievement of better CEP of energy firms. These findings are consistent with a broader view of the board of directors' function (MacMillan et al, 2004; Page, 2005), according to which the board's responsibilities go beyond the shareholders' wealth maximization, including also the attention to social and environmental issues. Moreover, our results align with prior investigations (Nederveen Pieterse et al. 2013), which suggest that cultural diversity improves team performance in terms of greater ability to process information, to discuss and integrate different perspectives and ideas. In this sense, the study contributes to the prior literature which identifies the cultural diversity on workgroups as a "double-edged sword" (Milliken and Martins, 1996; Phillips et al., 2006). Indeed, demonstrating the positive impact of cultural diversity on the amount of $\mathrm{CO} 2$ emissions, our empirical analysis suggests that cultural heterogeneity may improve the effectiveness of the board's decisions regarding environmental issues.

In a second step, the study demonstrates that the positive influence of the board's cultural diversity on CEP is stronger among energy firms from civil law countries compared to energy firms from common law countries. In this respect, our research enriches prior literature investigating how the determinants of firms' engagement in socially and environmentally responsible initiatives vary across different institutional contexts (Ortiz-de-Mandojana et al., 2016). Moreover, our empirical evidence corroborates the findings of previous investigations (e.g. Liang and Renneboog, 2017) arguing that the characteristics of civil law countries (e.g. lower shareholder protection, strong labor regulations, high state involvement in the businesses) favor the firms' achievement of better social and environmentally responsible performance.

However, despite the abovementioned contributions, the current research has some limitations that may be addressed by future studies. First, the analysis focuses on the amount of $\mathrm{CO} 2$ emissions to proxy CEP of energy firms. Future research may also measure CEP in terms, for example, of efficient use of water resources, impact on ecosystems and biodiversity, waste management. Second, we consider the firms operating in the energy sector as a whole future studies may advance our analysis distinguishing between fossil fuels and renewable energy firms. Finally, the study analyses how board cultural diversity effects on CEP varies across legal systems, 
future investigations may enrich the empirical evidence considering other institutional characteristics such as national cultural differences or degree of national economic development.

\section{References}

1. Abdullah, S. N., Ismail, K. N. I. K., \& Nachum, L. (2016). Does having women on boards create value? The impact of societal perceptions and corporate governance in emerging markets. Strategic Management Journal, 37(3), 466-476.

2. Aguilera RV, Jackson G. 2010. Comparative and international corporate governance. Academy of Management Annals 4: 485-556.

3. Anderson, R. C., Reeb, D. M., Upadhyay, A., \& Zhao, W. (2011). The economics of director heterogeneity. Financial Management, 40(1), 5-38.

4. Berrone, P., \& Gomez-Mejia, L. R. (2009). Environmental performance and executive compensation: An integrated agency-institutional perspective. Academy of Management Journal, 52(1), 103-126.

5. Birindelli, G., Iannuzzi, A. P., \& Savioli, M. (2019) The impact of women leaders on environmental performance: Evidence on gender diversity in banks. Corporate Social Responsibility and Environmental Management.

6. Busch, T., \& Lewandowski, S. (2018). Corporate Carbon and Financial Performance: A Meta-analysis. Journal of Industrial Ecology, 22(4), 745759.

7. Cadez, S., \& Czerny, A. (2016). Climate change mitigation strategies in carbon-intensive firms. Journal of Cleaner Production, 112, 4132-4143.

8. Calton, J. M., \& Payne, S. L. (2003). Coping with paradox: Multistakeholder learning dialogue as a pluralist sensemaking process for addressing messy problems. Business \& Society, 42(1), 7-42.

9. Carroll, A. B. (2000). Ethical challenges for business in the new millennium: Corporate social responsibility and models of management morality. Business Ethics Quarterly, 33-42.

10. Chams, N., \& García-Blandón, J. (2019). On the importance of sustainable human resource management for the adoption of sustainable development goals. Resources, Conservation and Recycling, 141, 109-122.

11. Dahlsrud, A. (2008). How corporate social responsibility is defined: an analysis of 37 definitions. Corporate social responsibility and environmental management, 15(1), 1-13.

12. das Neves, J. C., \& Melé, D. (2013). Managing ethically cultural diversity: Learning from Thomas Aquinas. Journal of business ethics, 116(4), 769-780.

13. de Abreu, M. C. S., de Freitas, A. R. P., \& Rebouças, S. M. D. P. (2017). Conceptual model for corporate climate change strategy 
development: Empirical evidence from the energy sector. Journal of cleaner production, 165, 382-392.

14. De Villiers, C., Naiker, V., \& Van Staden, C. J. (2011). The effect of board characteristics on firm environmental performance. Journal of Management, 37(6), 1636-1663.

15. Delmas, M. A., \& Toffel, M. W. (2008). Organizational responses to environmental demands: Opening the black box. Strategic Management Journal, 29(10), 1027-1055.

16. Deloitte Review. Bourke, J., \& Dillon, B. (2018). The diversity and inclusion revolution: Eight powerful truths. , 22, 82-95.

17. Dias, D., Zhu, C. J., \& Samaratunge, R. (2020). Examining the role of cultural exposure in improving intercultural competence: implications for HRM practices in multicultural organizations. The International Journal of Human Resource Management, 31(11), 1359-1378.

18. Doda, B., Gennaioli, C., Gouldson, A., Grover, D., \& Sullivan, R. (2016). Are corporate carbon management practices reducing corporate carbon emissions? Corporate Social Responsibility and Environmental Management, 23(5), 257-270.

19. Downie, J., \& Stubbs, W. (2013). Evaluation of Australian companies' scope 3 greenhouse gas emissions assessments. Journal of Cleaner Production, 56, 156-163.

20. European Environment Agency. Annual report (2019).

21. Ferreira, D. (2010). Board diversity. Corporate governance: A synthesis of theory, research, and practice, 8, 225.

22. Friedman, M. (1970). The social responsibility of business is to increase its profits. New York Times Magazine, September 13.

23. Frijns, B., Dodd, O., \& Cimerova, H. (2016). The impact of cultural diversity in corporate boards on firm performance. Journal of Corporate Finance, 41, 521-541.

24. Galbreath, J. (2018). Is board gender diversity linked to financial performance? The mediating mechanism of CSR. Business \& Society, 57(5), 863-889.

25. Gallego-Álvarez, I., Segura, L., \& Martínez-Ferrero, J. (2015). Carbon emission reduction: The impact on the financial and operational performance of international companies. Journal of Cleaner Production, 103, 149-159.

26. García Martín, C. J., \& Herrero, B. (2020). Do board characteristics affect environmental performance? A study of EU firms. Corporate Social Responsibility and Environmental Management, 27(1), 74-94.

27. Gill, A. (2008). Corporate governance as social responsibility: A research agenda. Berkeley J. Int'l L., 26, 452. 
28. Graafland, J. (2019). Economic freedom and corporate environmental responsibility: The role of small government and freedom from government regulation. Journal of Cleaner Production, 218, 250-258.

29. Haque, F. (2017). The effects of board characteristics and sustainable compensation policy on carbon performance of UK firms. The British Accounting Review, 49(3), 347-364.

30. Haque, F., \& Ntim, C. G. (2018). Environmental policy, sustainable development, governance mechanisms and environmental performance. Business Strategy and the Environment, 27(3), 415-435.

31. Helfaya, A., \& Moussa, T. (2017). Do board's corporate social responsibility strategy and orientation influence environmental sustainability disclosure? UK evidence. Business Strategy and the Environment, 26(8), 1061-1077.

32. Jain, T., \& Jamali, D. (2016). Looking inside the black box: The effect of corporate governance on corporate social responsibility. Corporate Governance: An International Review, 24(3), 253-273.

33. Jensen, M. C., \& Meckling, W. H. (1976). Theory of the firm: Managerial behavior, agency costs and ownership structure. Journal of financial economics, 3(4), 305-360.

34. Jo, H., \& Harjoto, M. A. (2011). Corporate governance and firm value: The impact of corporate social responsibility. Journal of business ethics, 103(3), 351-383.

35. Jo, H., Kim, H., \& Park, K. (2015). Corporate environmental responsibility and firm performance in the financial services sector. Journal of business ethics, 131(2), 257-284.

36. Jung, J., Herbohn, K., \& Clarkson, P. (2018). Carbon risk, carbon risk awareness and the cost of debt financing. Journal of Business Ethics, 150(4), 1151-1171.

37. Kassinis, G., Panayiotou, A., Dimou, A., \& Katsifaraki, G. (2016). Gender and environmental sustainability: A longitudinal analysis. Corporate Social Responsibility and Environmental Management, 23(6), 399-412.

38. Kim, Y. B., An, H. T., \& Kim, J. D. (2015). The effect of carbon risk on the cost of equity capital. Journal of Cleaner Production, 93, 279-287.

39. Kleimeier, S., \& Viehs, M. (2018). Carbon disclosure, emission levels, and the cost of debt. Emission Levels, and the Cost of Debt (January 7, 2018).

40. Kock, C. J., \& Min, B. S. (2016). Legal origins, corporate governance, and environmental outcomes. Journal of business ethics, 138(3), 507-524.

41. La Porta, R., Lopez-de-Silanes, F., \& Shleifer, A. (2008). The economic consequences of legal origins. Journal of economic literature, 46(2), 285-332. 
42. La Porta, Rafael, Florencio López-de-Silanes, Andrei Shleifer, and Robert W. Vishny, 1999, The quality of government, Journal of Law, Economics, and Organization 15, 222-279.

43. Landry, E. E., Bernardi, R. A., \& Bosco, S. M. (2016). Recognition for sustained corporate social responsibility: Female directors make a difference. Corporate Social Responsibility and Environmental Management, 23(1), 27-36.

44. Lannelongue, G., Gonzalez-Benito, J., \& Gonzalez-Benito, O. (2015).

Input, output, and environmental management productivity: effects on firm performance. Business Strategy and the Environment, 24(3), 145-158.

45. Lee, S.Y., Park, Y.S. and Klassen, R.D. (2015), "Market responses to firms' voluntary climate change information disclosure and carbon communication", Corporate Social Responsibility and Environmental Management, Vol. 22 No. 1, pp. 1-12.

46. Lemma, T. T., Feedman, M., Mlilo, M., \& Park, J. D. (2019). Corporate carbon risk, voluntary disclosure, and cost of capital: S outh A frican evidence. Business Strategy and the Environment, 28(1), 111-126.

47. Lewandowski, S. (2017). Corporate carbon and financial performance: The role of emission reductions. Business Strategy and the Environment, 26(8), 1196-1211.

48. Li, D., Cao, C., Zhang, L., Chen, X., Ren, S., \& Zhao, Y. (2017). Effects of corporate environmental responsibility on financial performance: The moderating role of government regulation and organizational slack. Journal of cleaner production, 166, 1323-1334.

49. Liang, H., \& Renneboog, L. (2017). On the foundations of corporate social responsibility. The Journal of Finance, 72(2), 853-910.

50. Liao, L., Luo, L., \& Tang, Q. (2015). Gender diversity, board independence, environmental committee and greenhouse gas disclosure. The British Accounting Review, 47(4), 409-424.

51. Lozano, J. F., \& Escrich, T. (2017). Cultural diversity in business: A critical reflection on the ideology of tolerance. Journal of Business Ethics, 142(4), 679-696.

52. MacMillan, K., Money, K., Downing, S., \& Hillenbrand, C. (2004). Giving your organisation SPIRIT: an overview and call to action for directors on issues of corporate governance, corporate reputation and corporate responsibility. Journal of General Management, 30(2), 15-42.

53. Maznevski, M. L. (1994). Understanding our differences: Performance in decision-making groups with diverse members. Human relations, 47(5), 531-552.

54. McWilliams, A., \& Siegel, D. (2001). Corporate social responsibility: A theory of the firm perspective. Academy of management review, 26(1), 117-127. 
55. Milliken, F. J., \& Martins, L. L. (1996). Searching for common threads: Understanding the multiple effects of diversity in organizational groups. Academy of management review, 21(2), 402-433.

56. Naciti, V. (2019). Corporate governance and board of directors: The effect of a board composition on firm sustainability performance. Journal of Cleaner Production, 237, 117727.

57. Nederveen Pieterse, A., Van Knippenberg, D., \& Van Dierendonck, D. (2013). Cultural diversity and team performance: The role of team member goal orientation. Academy of Management Journal, 56(3), 782-804.

58. Ortas, E., Burritt, R. L., \& Christ, K. L. (2019). The influence of macro factors on corporate water management: A multi-country quantile regression approach. Journal of Cleaner Production, 226, 1013-1021.

59. Ortiz-de-Mandojana, N., Aguilera-Caracuel, J., \& Morales-Raya, M.

(2016). Corporate governance and environmental sustainability: The moderating role of the national institutional context. Corporate Social Responsibility and Environmental Management, 23(3), 150-164.

60. Page, J. P. (2005). Corporate governance and value creation.

61. Phillips, K. W., Northcraft, G. B., \& Neale, M. A. (2006). Surfacelevel diversity and decision-making in groups: When does deep-level similarity help? Group processes \& intergroup relations, 9(4), 467-482.

62. Post, C., Rahman, N., \& Rubow, E. (2011). Green governance: Boards of directors' composition and environmental corporate social responsibility. Business \& Society, 50(1), 189-223.

63. Qian, W., \& Xing, K. (2018). Linking Environmental and Financial Performance for Privately Owned Firms: Some Evidence from A ustralia. Journal of Small Business Management, 56(2), 330-347.

64. Sharfman, M. P., Shaft, T. M., \& Tihanyi, L. (2004). A model of the global and institutional antecedents of high-level corporate environmental performance. Business \& Society, 43(1), 6-36.

65. Shen, J., Wei, Y. D., \& Yang, Z. (2017). The impact of environmental regulations on the location of pollution-intensive industries in China. Journal of cleaner production, 148, 785-794.

66. Shleifer, A., \& Vishny, R. W. (1997). A survey of corporate governance. The Journal of Finance, 52(2), 737-783.

67. Stirling, Andrew (1998), 'On the Economics and Analysis of Diversity', SPRU Electronic Working Papers Series, 28.

68. Thomson Reuters Eikon (2018). Thomson Reuters ESG Scores. https://www.refinitiv.com/content/dam/gl/en/documents/ methodology/esgscoresmethodology.pdf. 
69. Tsui, A. S., \& O'reilly III, C. A. (1989). Beyond simple demographic effects: The importance of relational demography in superior-subordinate dyads. Academy of management journal, 32(2), 402-423.

70. Wooldridge, J. M. (2002). Econometric analysis of cross section and panel data MIT Press. Cambridge, MA, 108. 